\title{
Local Fruit Waste Driven Benthic Microbial Fuel Cell: A Sustainable Approach to Toxic Metal Removal and Bioelectricity Generation
}

\author{
Asim Ali Yaqoob \\ Universiti Sains Malaysia \\ Claudia Guerrero-Barajas \\ Instituto Politécnico Nacional: Instituto Politecnico Nacional \\ Mohamad Nasir Mohamad Ibrahim ( $D$ mnm@usm.my) \\ Universiti Sains Malaysia \\ Khalid Umar \\ Universiti Sains Malaysia \\ Amira Suriaty Yaakop \\ Universiti Sains Malaysia
}

\section{Research Article}

Keywords: Benthic microbial fuel cell, Wastewater, Heavy Metals, Bioenergy, Bacteria identification

Posted Date: August 23rd, 2021

DOI: https://doi.org/10.21203/rs.3.rs-760370/v1

License: (c) (1) This work is licensed under a Creative Commons Attribution 4.0 International License. Read Full License

Version of Record: A version of this preprint was published at Environmental Science and Pollution Research on January 12th, 2022. See the published version at https://doi.org/10.1007/s11356-02117444-z. 

Metal Removal and Bioelectricity Generation

4 Umar $^{1 *}$, Amira Suriaty Yaakop ${ }^{3}$

$5 \quad{ }^{1}$ Materials Technology Research Group (MaTRec), School of Chemical Sciences, Universiti Sains 6 Malaysia, 11800 Minden, Penang, Malaysia.

$7 \quad{ }^{2}$ Laboratorio de Biotecnología Ambiental, Departamento de Bioprocesos, Unidad Profesional

8 Interdisciplinaria de Biotecnología, Instituto Politécnico Nacional, Av. Acueducto s/n, Col. Barrio

$9 \quad$ La Laguna Ticomán, 07340 Mexico City, Mexico

$10{ }^{3}$ School of Biological Sciences, Universiti Sains Malaysia, Pulau Pinang 11800, Malaysia

*Corresponding authors: mnm@usm.my (M.N.M.I); khalidumar4@gmail.com (K.U)

\section{Abstract:}

The present work focused on the utilization of three local wastes i.e., rambutan (nephelium

14 lappaceum), langsat (lansium parasiticum) and mango (mangifera indica) wastes as organic substrates in benthic microbial fuel cell (BMFC) to reduce the cadmium and lead concentrations from synthetic wastewater. Out of the three wastes, the mango waste promoted a maximum current 17 density $\left(87.71 \mathrm{~mA} / \mathrm{m}^{2}\right)$ along with $78 \%$ and $80 \%$ removal efficiencies for $\mathrm{Cd}^{2+}$ and $\mathrm{Pb}^{2+}$, 18 respectively. The bacterial identification proved that Klebsiella pneumoniae, Enterobacter, and 19 Citrobacter were responsible for metals removals and energy generation. Lastly, the BMFC mechanism, challenges and future recommendations are enclosed.

21 Keywords: Benthic microbial fuel cell; Wastewater; Heavy Metals; Bioenergy; Bacteria 22 identification. 


\section{Introduction:}

Modern human society faces critical challenges arising from the crisis of renewable energy and clean water supply around the world. This problem arises mainly due to population growth and industrial activities in which several other factors are also involved (Yaqoob et al. 2020c). Despite all the developments, there are still issues that need to be solved, which prompts researchers to find economical, environmentally friendly, fast, and reliable methods to produce bioenergy and control water pollution. In the modern world, high demand for energy is increasing due to the use of non -renewable energy at the industrial level which is causing a decline in natural fossil fuels. Rapid industrial growth is primarily responsible for the energy crisis, moreover, the practice of solid waste burning has caused serious damage to water resources. Water pollution has a direct impact on human survival. Currently, the world faces the presence of heavy metals in water sources that can cause serious health problems. Therefore, there is a critical challenge to find mechanisms to control water pollution and at the same time produce bioenergy. To address these issues, several studies suggested that the microorganisms can act as catalysts (i.e., Geobacter sp., E. Coli, Pseudomonas sp. etc.) to produce bioenergy and minimize the heavy metal concentration from water resources (Fadzli et al. 2021a, Logan et al. 2006, Yaqoob et al. 2020b). Microbial fuel cells (MFC) has been introduced as an environmental biotechnology practice that has received a lot of attention from researchers. MFC is an environmentally friendly system and a safe approach to wastewater treatment, but it requires a synthetic organic substrate, which serves as a fuel to promote effective oxidation by microorganisms (Asim et al. 2021, Logan et al. 2006). This is especially true in cases where highly electrogenic microorganism strains (such as Geobacter sp.) are involved in the system (Li et al. 2018, Logan 2009). 
Recently, an updated version of MFC has been introduced to remediation practices to

47 utilize naturally derived organic substrates to replace synthetic organic substrates. This version of

the MFC is a benthic microbial fuel cell (BMFC), which operates based on the same concept as the MFC (Nielsen et al. 2007, Yaqoob et al. 2021b). The main difference between BMFC and MFC is the use of organic substrates derived from the reduction of organic matter that occurs naturally in the environment. BMFC does not require the addition of external fuels as bacterial feed during its process (Umar et al. 2021). BMFC uses natural waste as an organic substrate in the anodic space to promote bacterial growth for the oxidation process and this waste also serves as a pseudo-membrane to allow proton flow in BMFC. Anaerobic bacteria function in the anodic chamber of the BMFC, whereas the cathode is exposed to aerated conditions (Umar et al. 2020). In several studies reported the use of organic substrates derived from waste in MFC, however little work needs to be done for BMFC cases, especially those related to heavy metal removal (Joiner et al. 2020, Pushkar \&Mungray 2020, Tavakolian et al. 2020). According to Vilarino Franco and Quarrington (2017), about 1.3 billion tons of food is wasted each year worldwide (Vilariño et al. 2017) . The BMFC system is an efficient approach to minimize waste from the environment and produce bioenergy by using waste materials.

In the present work, some local fruit wastes such as rambutan (nephelium lappaceum), langsat (lansium parasiticum), and mango (mangifera indica) were utilized as organic substrates in BMFC to promote bacterial activity during the generation of electrons and protons. Rambutan, langsat, and mango are suitable to be grown throughout Malaysia and several Southeast Asian nations such as Indonesia and Thailand. These fruits will produce waste in the form of skins and seeds. The targeted wastes are rich sources of organic matter (carbohydrates and glucose) as having been reported in the literature. To our knowledge, at present, there is no work on the use of these 
wastes in BMFC even though these are very rich organic resources and is available in relatively large quantities in Malaysia. In addition, our work demonstrates that BMFC is capable of being a generator of bioenergy, which is derived from the oxidation of natural wastes in the anodic space in a process combined with the removal of heavy metals from synthetic wastewater. This work is limited to the removal of cadmium and lead ions. Furthermore, this study also focuses on the optimization of parameters ( $\mathrm{pH}$ and temperature) to improve BMFC performance.

\section{MATERIALS AND METHODS}

\subsection{Sample preparation and inoculum source}

Targeted wastes such as rambutan, langsat, and mango waste were received from the local market of Penang, Malaysia. The waste is gently washed to remove impurities and cut into small pieces. These small pieces of garbage are stored at room temperature. Similarly, synthetic wastewater was prepared by collecting wastewater from a pond in Gelugor, Penang, Malaysia, which was further supplemented with a solution of lead nitrate (Sigma-Aldrich) and 50-ppm cadmium nitrate (SigmaAldrich). The physiochemical properties of the wastewater collected before and after treatment are shown in Table 1. The treated wastewater is known as synthetic wastewater in the present study. Electrical conductivity (ECM) (measured by an Alpha-800 conductivity meter), liquid temperature (measured with a GH thermometer, ZEAL LTD, England), and pH (measured with an EUTECH700 USA pH meter), were used to determine conductivity, temperature, and wastewater $\mathrm{pH}$.

Table 1: Physicochemical properties of the collected wastewater before and after metal supplementation

\begin{tabular}{lll}
\hline Parameters & Untreated wastewater & Treated wastewater \\
Color & Light black & Light black \\
Odor & unfriendly smell & unfriendly smell
\end{tabular}




\begin{tabular}{lll}
\hline $\mathrm{pH}$ & 7.04 & 6.50 \\
Temperature & $25-30^{\circ} \mathrm{C}$ & $25-30^{\circ} \mathrm{C}$ \\
Electrical conductivity & $59 \mu \mathrm{S} / \mathrm{cm}$ & $80 \mu \mathrm{S} / \mathrm{cm}$ \\
$\mathrm{Cd}^{2+}$ & $0 \mathrm{ppm}$ & $50 \mathrm{ppm}$ \\
$\mathrm{Pb}^{2+}$ & $0 \mathrm{ppm}$ & $50 \mathrm{ppm}$ \\
\hline
\end{tabular}

89

\subsection{Benthic microbial fuel cells construction and operation}

A double chamber BMFC was constructed by joining two commercial cylindrical glasses. The dimensions for the constructed BMFC chambers (anode and cathode) were $10 \mathrm{~cm}$ in length and $10 \mathrm{~cm}$ in diameter. The total volume of one chamber was $500 \mathrm{~mL}$ and the working volume was $400 \mathrm{~mL}$. The anodic chamber was filled with synthetic wastewater $(400 \mathrm{~mL})$ along with waste material (each waste was $150 \mathrm{~g}$ ) as an organic substrate for bacteria. The supplemented metal ions were present in synthetic wastewater. The mixed culture of bacterial species was present as the inoculum which oxidizes the organic substrate. The graphite rod (GF series, FUDA 2B Lead, NY, USA) with dimensions of $10 \mathrm{~cm} \times 2 \mathrm{~cm}(\mathrm{~h} \times \mathrm{r})$ served as anode and cathode electrodes in both chambers. The carbon-based material is an efficient source for remediation and energy applications [16]. The distance between the two electrodes was $7 \mathrm{~cm}$. The BMFC anodic chamber was closed to maintain an anaerobic atmosphere, whereas the cathodic chamber was filled with aerated tap water. To maintain an airy environment in the cathodic space, an aquarium pump was used to supply oxygen. These features make BMFC more prominent than MFC, which saves time and effort due to the simultaneous use of natural waste and energy generation. A medium-size copper wire was used throughout the operation to provide external loads $(560 \Omega)$. Three types of local fruit wastes were used as organic substrates in the anodic chamber. The performance of BMFC 
with each of these residues was labeled as: BMFC-I (rambutan waste), BMFC-II (langsat waste), and BMFC-III (mango waste). All BMFC experiments were performed in a similar manner as described above. All BMFC experiments were performed at room temperature under continuous operation for 45 days. To evaluate and optimize the influence of $\mathrm{pH}$ and temperature on energy generation and metal removal efficiency, $\mathrm{pH}$ was assessed in the range of 3-10 and temperature in the range of $15-35^{\circ} \mathrm{C}$ in each case. The lab scale design of the BMFC is shown in Fig. 1.

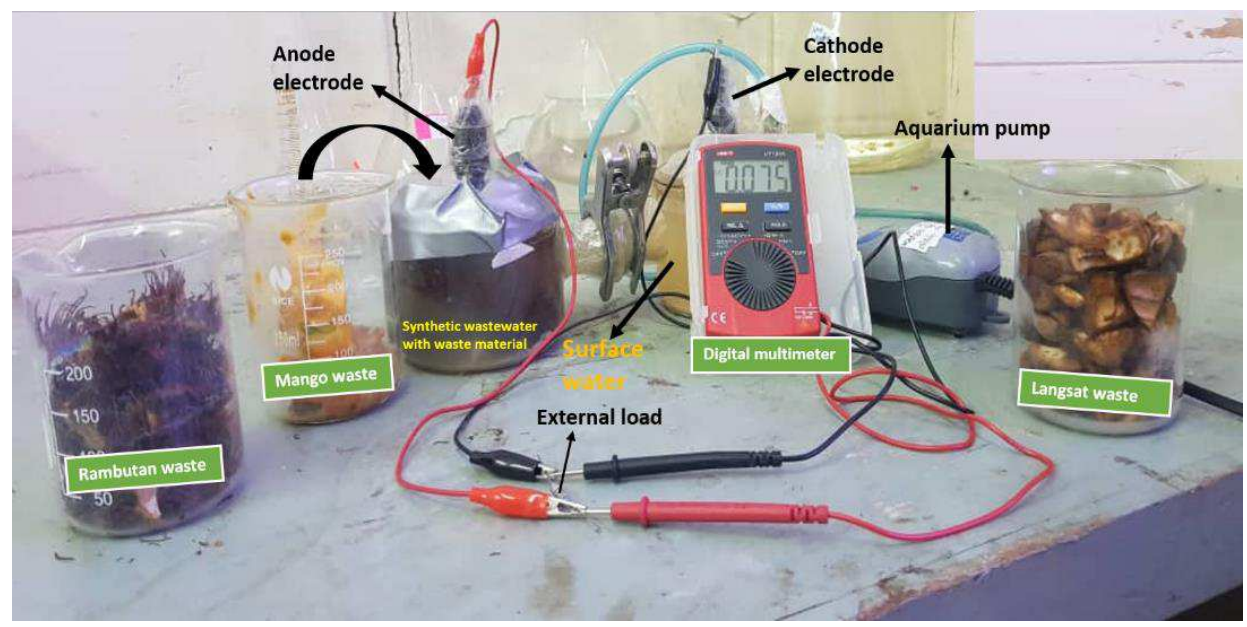

Fig. 1: Graphic presentation of the BMFC system.

\subsection{Electrochemical measurements}

The cell potential voltage (V) was recorded using a digital multimeter (UNI-T, Model UT120A, China). The voltage of each BMFC is measured once a day and Ohm's law is followed to calculate the current density/power density of each cell. The following equations were used to calculate the force density (PD) and current density (CD), as well as the current and internal resistance of the cell (Chen et al. 2017, Salvin et al. 2015). 
125

126

127

128

129

130

131

132

133

where,

$\mathrm{V}=$ potential voltage; $\mathrm{r}=$ internal resistance; $\mathrm{I}=$ current; $\mathrm{R}=$ external resistance; $\mathrm{A}=$ surface area; $\mathrm{E}=$ Electromotive force (Emf). The value of E can be determined by employing the open-circuit voltage (OCV). Further, the polarization curve (V-I) was studied by following the 'Rext-variation' system which was defined by Logan et al. (Logan et al. 2006). An adjustable resistor box was attached to the system to regulate the external resistance of the cell from $10 \mathrm{k} \Omega$ to $100 \Omega$ (opencircuit t-short-circuit). The value of each resistance was measured after the establishment of the pseudo-steady state. Usually, a 10-20 min variation was required during measurements. Therefore, the polarization curve was calculated, and it illustrates the relationship power (P) versus I. Similarly, the internal resistance calculation was carried out by following Equation 4.

Furthermore, cyclic Voltammetry (CV) was carried out to study the redox reaction status during the operation of BMFC-I, BMFC-II, and BMFC-III. CV measurements were carried out at different time intervals i.e., on the 15th day, 30th day, and 45th day. The CV measurement protocol was as follows: $20 \mathrm{mV} / \mathrm{s}$ rate in a -0.8 to $+0.8 \mathrm{~V}$ of potential range. The glassy carbon, $\mathrm{Ag} / \mathrm{AgCl}$, and Pt wire were used during the measurements as the working electrode, counter electrode, and reference electrode, respectively.

In addition, to complete the $\mathrm{CV}$ evaluation, the specific capacitance $(\mathrm{Cp},(\mathrm{F} / \mathrm{g}))$ was also calculated. Equation 5 is used to calculate the value of $\mathrm{Cp}$.

$\mathrm{C}_{\mathrm{p}}=\frac{\mathrm{A}}{2 \mathrm{mk}(\mathrm{V} 2-\mathrm{V} 1)}$

where, $(V 2-V 1)=$ potential range of $\mathrm{CV} ; \mathrm{m}=$ loaded sample $(\mathrm{g}), \mathrm{A}=$ area of $\mathrm{CV}$ curves $(\mathrm{AV}), \mathrm{k}$ $=$ scan rate of $\mathrm{CV}$ in $\mathrm{mV} / \mathrm{s}$.

\subsection{Metal removal analyses and biological studies}


147 The metal analysis was carried out through an atomic absorption spectrometer (PerkinElmer 148 AAnalyst 400). Each cell BMFC-I, BMFC-II, and BMFC-III was filled with synthetic wastewater 149 and targeted wastes which contained a 50-ppm solution of $\mathrm{Cd}^{+2}$ and $\mathrm{Pb}^{+2}$. A sample of $1.5 \mathrm{~mL}$ of 150 the synthetic wastewater was taken every 10 days according to the planned schedule. Equation 6

151

152 was used to calculate the removal efficiency of the metals from the cells.

$\mathrm{R} . \mathrm{E} \%=\frac{\mathrm{TM} i-\mathrm{TM} f}{\mathrm{TM} i} \times 100$

where, R.E.= removal efficiency \%; $\mathrm{TMi}=$ total initial toxic metal concentration; $\mathrm{TMf}=$ total final toxic metal concentration. Scanning electron microscopy (SEM) was used to study the biofilm morphology. Biofilm is a conglomerate of bacteria formed on the surface of the anode, which is responsible for metal removal. The SEM images of the biofilm showed the presence of bacteria on the surface of the anode which generally is involved in the metal removal mechanism as has been already discussed in previous studies (Chen et al. 2011, Rajeswari et al. 2016, Tang et al. 2014). To identify the bacterial species involved in the process occurring at the anode surface of each BMFC (BMFC-I, BMFC-II, and BMFC-III), isolation and identification of bacteria were performed. At the end of the operation, the anode was treated with sterilized water before the biofilm was carefully pruned using a sterilized knife. The collected biofilm was further treated through a serial dilution process (10-1 to 10-9) for bacterial growth on nutrient agar plates until the growth of single colonies was observed. The pure colonies were further assessed through colony polymerase chain reaction (PCR). The PCR was carried out to amplify the DNA extracted from the isolated bacteria. The $1492 \mathrm{R}$ reverse primer and $27 \mathrm{~F}$ forward primer were used for the amplification. The $16 \mathrm{~S}$ rRNA sequences were submitted to the GenBank under the accession numbers listed in Table 5.

\section{Results and Discussion}




\subsection{Energy output from natural wastes without any substrate additional in BMFC}

The observed potential voltage outputs of the BMFC-I, BMFC-II, and BMFC-III systems made with a fresh inoculum source and an external load of $560 \Omega$, are shown in in Figure 2a.

According to the curves of the three BMFC systems observed, a major difference was observed in the voltage generation on the first day in the presence of an external load of $560 \Omega$. All BMFC operations were carried out for 45 days until the voltage dropped to the lower limit. Open-circuit voltages were also observed at the beginning of the reaction without external resistance, these values being $300 \mathrm{mV}$ (BMFC-I), $270 \mathrm{mV}$ (BMFC-II), and $490 \mathrm{mV}$ (BMFC-III). The power outputs of BMFC-I, BMFC-II, and BMFC-III on the first day were $0.017 \mathrm{~mA}, 0.001 \mathrm{~mA}$, and $0.026 \mathrm{~mA}$, respectively. The current generation difference is quite high between BMFC-I and BMFC-II. Similarly, the highest output current difference was $0.025 \mathrm{~mA}$ observed in BMFC-II and BMFCIII. BMFC-I showed the highest voltage on the $20^{\text {th }}$ day $(170 \mathrm{mV})$, BMFC-II showed the highest voltage on the $24^{\text {th }}$ day $(100 \mathrm{mV})$ and BMFC-III showed $180 \mathrm{mV}$ on the $18^{\text {th }}$ day. According to the observed potential, the highest calculated current densities were $39.94 \mathrm{~mA} / \mathrm{m}^{2}$ (BMFC-I), $23.49 \mathrm{~mA} / \mathrm{m}^{2}$ (BMFC-II), and $42.29 \mathrm{~mA} / \mathrm{m}^{2}$ (BMFC-III). Further, after reaching the highest point, the voltage starts to drop sharply to reach the minimum level, this is true for BMFC-I, and BMFCII, which showed a minimum of $0 \mathrm{mV}$ on the 40th day and BMFC-III shows $1 \mathrm{mV}$ on the $42^{\text {nd }}$ day. The BMFC voltage decreases sharply after a certain point because the level of the organic substrate, which was the food source of bacteria was decreasing in the anodic space. The highest voltage point also indicated the maximum removal of metal ions $\left(\mathrm{Pb}^{2+}\right.$ and $\mathrm{Cd}^{2+}$ ions $)$ from the wastewater. Overall, the presence of mango waste (skin and seeds) in BMFC-III was associated with the highest voltage and stability during operation compared to other cells (BMFC-I and 
BMFC-II). The results indicated that the level of glucose in the waste was an important factor in maintaining bacterial growth and electron generation during bacterial respiration.

\subsection{Electrochemical measurement}

To analyze the effect of PD vs V, various external resistances were tested (150 $\Omega-7 \mathrm{k} \Omega$ ). High external resistances such as $7 \mathrm{k} \Omega$ or $6 \mathrm{k} \Omega$ indicated fast potential stability, but the $\mathrm{CD}$ and PD trends lead to lower values compared to low external resistances such as 150,200 or $560 \Omega$. Similarly, voltage instability was lower at higher external resistances $(2-7 \mathrm{k} \Omega)$ than at lower external resistances $(150,300,560 \Omega)$. High voltage instability at lower external resistances due to the flow of electrons towards the anode was effective because there was little resistance interfering with the flow. Similarly, high resistance prevents the flow of electrons during the transformation of organic matter toward the cathode, which resulted in low voltage stabilization. In the present work, all BMFC were connected to a resistance box by varying the external resistance from 150 $\Omega$ to $7 \mathrm{k} \Omega$. The voltage values from a high resistance $(7 \mathrm{k} \Omega)$ to a lower resistance $(150 \Omega)$ were of $290 \mathrm{mV}$ to $42 \mathrm{mV}$ (BMFC- I), $220 \mathrm{mV}$ to $45 \mathrm{mV}$ (BMFC- II), and $400 \mathrm{mV}$ to $100 \mathrm{mV}$ (BMFCIII) as shown in Fig. 2 (a-d). The voltage was shifting from a high to a low value as the variation of the resistances shifted from high to low ( $7 \mathrm{~K} \Omega$ to $15 \Omega$ ). However, the highest $\mathrm{CD}$ recorded was of $36.84 \mathrm{~mA} / \mathrm{m}^{2}$ (for BMFC- I), $39.96 \mathrm{~mA} / \mathrm{m}^{2}$ (for BMFC- II), and $87.71 \mathrm{~mA} / \mathrm{m}^{2}$ (for BMFC- III) at lower resistances. Similarly, PD values were recorded as $0.30 \mathrm{~mW} / \mathrm{m}^{2}$ (BMFC-I), $0.22 \mathrm{~mW} / \mathrm{m}^{2}$ (BMFC-II) and $0.71 \mathrm{~mW} / \mathrm{m}^{2}$ (BMFC-III) at external resistances of $560 \Omega$ and $450 \Omega$. Similarly, the internal resistance of the cell was also important for the release of electrons from the anode to the cathode. Equation 4 was used to calculate the internal resistance of the cell for 45 days of BMFC operation. BMFC- I, BMFC- II, and BMFC- III showed internal resistance values of 560, 
728 and $544 \Omega$, respectively from which the PD/CD ratio can be obtained with this internal resistance. Usually, an external oxygen supply also helps stabilize the voltage at high resistance.

A similar trend was also observed by Reimers et al. (2006), they recommended the use of BMFC in naturally rich organic substrates to improve BMFC performance. Nielsen et al. (2007) also recommended a new design for BMFC with natural waste as the organic substrate in the anodic space to achieve the highest pollution elimination and energy generation.
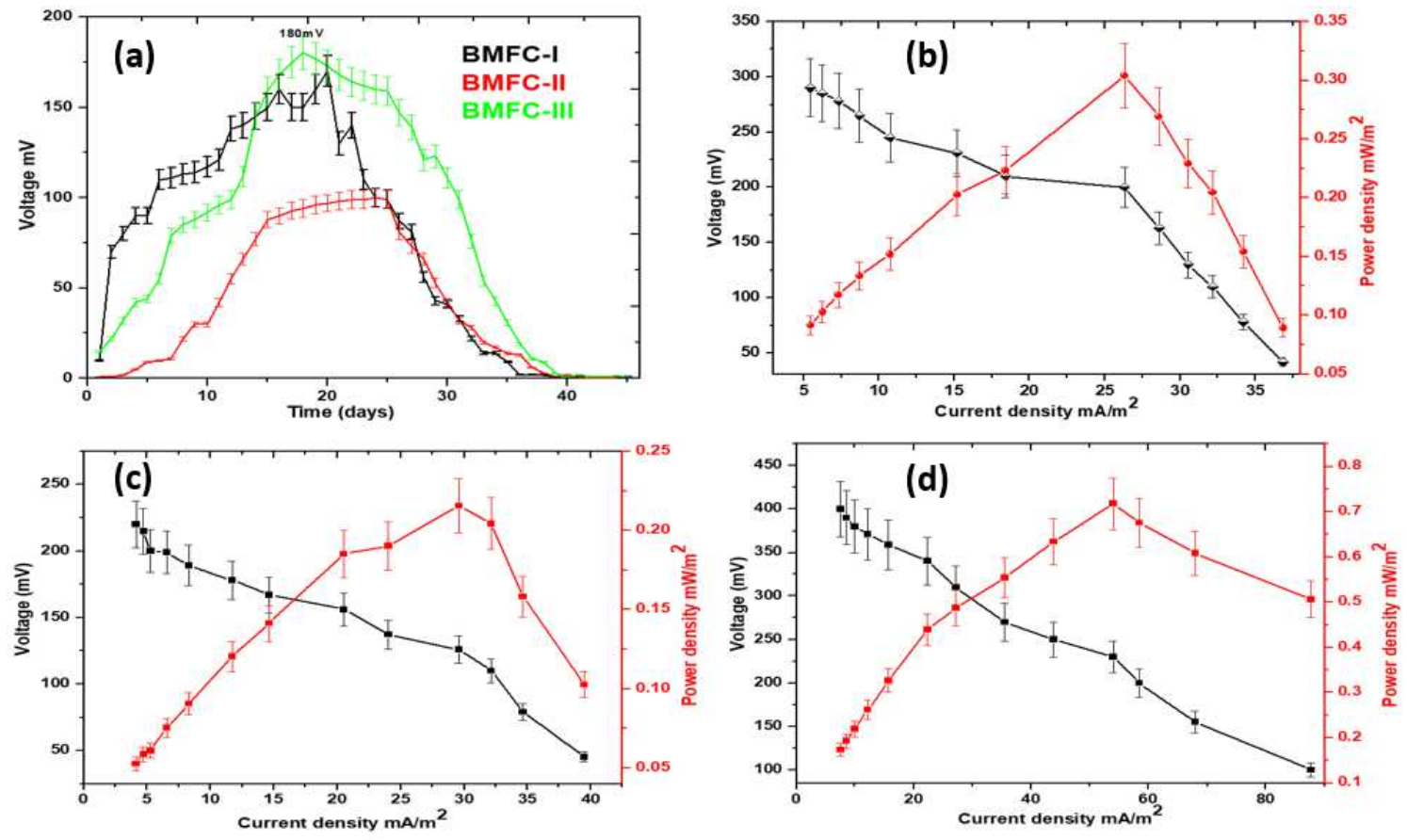

Fig. 2: (a) Observed voltages for BMFC- I, BMFC- II and BMFC-III (b) polarization curves of BMFC- I (c) polarization curves of BMFC- II (d) polarization curves of BMFC- III with external load variations from $150 \Omega$ to $7 \mathrm{k} \Omega$.

$\mathrm{CV}$ analysis showed the bacterial biomass of the electrodes at different time intervals to assess the rate of oxidation and reduction during operation. Each BMFC was analyzed separately at different time intervals to observe oxidation and reduction rates. BMFC-I showed maximum currents in the forward scan at $1.0 \times 10^{-5} \mu \mathrm{A}$ (on the $15^{\text {th }}$ day), $6.4 \times 10^{-5} \mu \mathrm{A}$ (on the $30^{\text {th }}$ day), and $8.0 \times 10^{-5} \mu \mathrm{A}$ (on the $45^{\text {th }}$ day), while the other part of the scan showed $-0.0 \times 10^{-5} \mu \mathrm{A}$ (on the $15^{\text {th }}$ day), $-0.5 \times$ 
$10^{-5} \mu \mathrm{A}$ (on the $30^{\text {th }}$ day), and $-1.1 \times 10^{-5} \mu \mathrm{A}$ (on the $45^{\text {th }}$ day). BMFC-II showed maximum currents in the forward scan at $1.1 \times 10^{-5} \mu \mathrm{A}$ (Day $15^{\text {th }}$ ), $4.3 \times 10^{-5} \mu \mathrm{A}$ (Day $30^{\text {th }}$ ), and $5.4 \times 10^{-5} \mu \mathrm{A}$ (Day $45^{\text {th }}$ ), whereas for the reverse scan it showed $-0.2 \times 10^{-5} \mu \mathrm{A}$ (Day $15^{\text {th }}$ ), $-0.8 \times 10^{-5} \mu \mathrm{A}$ (Day $30^{\text {th }}$ ), and $1.0 \times 10^{-5} \mu \mathrm{A}$ (Day $45^{\text {th }}$ ). Similarly, BMFC-III showed in the forward scan of $0.9 \times 10^{-5} \mu \mathrm{A}$ (Day $\left.15^{\text {th }}\right), 1.5 \times 10^{-5} \mu \mathrm{A}$ (Day $30^{\text {th }}$ ), and $3.0 \times 10^{-5} \mu \mathrm{A}\left(\right.$ Day $45^{\text {th }}$ ), whereas in the reverse scan it showed $0.2 \times 10^{-5} \mu \mathrm{A}$ (Day $\left.15^{\text {th }}\right),-1.2 \times 10^{-5} \mu \mathrm{A}$ (Day $30^{\text {th }}$ ), and $-5.5 \times 10^{-5} \mu \mathrm{A}$ (Day $45^{\text {th }}$ ). According to the results, the BMFC-I, BMFC-II, and BMFC-III showed the maximum current at forward and reverse scans rate on the $45^{\text {th }}$ day. The forward and reverse scans rate are indication of the rates of reduction and oxidation during the BMFC operation. The results showed that the rate of reduction and oxidation gradually increased and achieved a maximum on the $45^{\text {th }}$ day. It is also an indication that the operation in the cell has been completed. Afterward, the metal reduction, as well as voltage generation, was gradually decreasing due to the completion of the bacterial life cycle or completion of the operation of the cell. With respect to oxidation ( $\left.E_{\text {oxid }}\right)$ and reduction $\left(E_{\text {red }}\right)$ for each BMFC operation, the results are as follows: the BMFC-I showed $\mathrm{E}_{\text {oxid }}=0.8 \mathrm{~V}$ and $\mathrm{E}_{\text {red }}=-0.8 \mathrm{~V}$ on the $15^{\text {th }}$ day; $\mathrm{E}_{\text {oxid }} 0.8 \mathrm{~V}$ and $-0.79 \mathrm{~V}_{\text {red }}$ on day $30^{\text {th }}$ and $\mathrm{E}_{\text {oxid }} 0.8 \mathrm{~V}$ and $-0.78 \mathrm{~V} \mathrm{E}_{\text {red }}$ on day $45^{\text {th }}$. The BMFCII showed $E_{\text {oxid }} 0.8 \mathrm{~V}$ and $-0.8 \mathrm{~V} \mathrm{E}_{\text {red }}$ on day $15^{\text {th }} ; \mathrm{E}_{\text {oxid }} 0.8 \mathrm{~V}$ and $-0.79 \mathrm{~V} \mathrm{E}_{\text {red }}$ on day $30^{\text {th }}$ and $\mathrm{E}_{\text {oxid }}$ $0.8 \mathrm{~V}$ and $-0.77 \mathrm{~V} \mathrm{E}_{\text {red }}$ on day $45^{\text {th }}$. The BMFC-III showed $\mathrm{E}_{\text {oxid }} 0.8 \mathrm{~V}$ and $-0.78 \mathrm{~V} \mathrm{E}_{\text {red }}$ on day $15^{\text {th }}$; $\mathrm{E}_{\text {oxid }} 0.8 \mathrm{~V}$ and $-0.76 \mathrm{~V}$ E $\mathrm{red}_{\text {on }}$ day $30^{\text {th }}$ and $\mathrm{E}_{\text {oxid }} 0.8 \mathrm{~V}$ and $-0.75 \mathrm{~V} \mathrm{E}_{\text {red }}$ on day $45^{\text {th }}$. Each BMFC operation showed a higher rate of oxidation at the beginning as compared to the later days. The reduction rate also decreased at the end of the reaction, which indicates the completion of the operation. In literature, various studies reported this trend (Xu et al. 2017, Yaqoob et al. 2021a). For example, Yaqoob et al. (2020a) demonstrated that the lignin-derived GO anodes in the presence of oil palm trunk sap as organic substrate can promote the removal of lead ions from 
252 synthetic wastewater. These authors followed a similar procedure to elaborate and support their 253 results.

254 In addition, other parameters were considered to evaluate the trend of biofilm formation at 255 the BMFC anode during operation. The CV curve allows the determination of $\mathrm{C}_{\mathrm{s}}$. The calculated $256 \mathrm{C}_{\mathrm{s}}$ showed that the biofilm had excellent strength throughout the operation. High $\mathrm{C}_{\mathrm{s}}$ values 257 indicated good biofilm stability and formation. In this study, each BMFC system showed stable 258 biofilm activity as shown in Table 2. Several studies have also found similar observations to 259 explain and indicate strong biofilm formation (Daud et al. 2021, Fadzli et al. 2021b, Yaqoob et al. $2602020 a)$.

261 Table 2: Calculated specific capacitance, $\mathrm{C}_{\mathrm{s}}$, data from $\mathrm{CV}$ curves during the operation of each 262 BMFC.

\begin{tabular}{llll}
\hline Measurement & \multicolumn{3}{c}{ Specific Capacitance (F/g) } \\
\cline { 2 - 4 } time interval & BMFC-I & BMFC-II & BMFC-III \\
(days) & & & \\
$15^{\text {th }}$ & 0.00004 & 0.00006 & 0.00043 \\
$30^{\text {th }}$ & 0.00008 & 0.00008 & 0.00052 \\
$45^{\text {th }}$ & 0.00011 & 0.00011 & 0.00059 \\
\hline
\end{tabular}



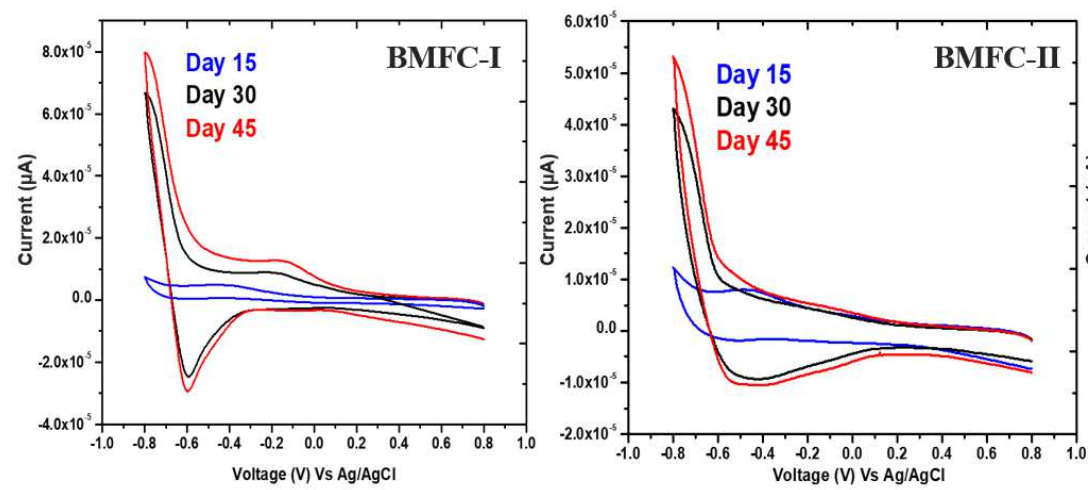

Fig. 3: CV behavior of BMFC-I, BMFC-II and BMFC-III at different time intervals during the operation.

\subsection{Effect of $\mathrm{pH}$ on energy generation in the presence of natural waste in BMFC}

According to the observations, Fig. 4a shows a direct relationship between the $\mathrm{pH}$ of the solution and voltage generation. The BMFC were operated at the different ranges of $\mathrm{pH}$ solution in the anodic chamber. The $\mathrm{pH}$ of the solutions (BMFC- I, BMFC-II, BMFC-III) was adjusted by using either $1 \mathrm{M} \mathrm{NaOH}$ or $1 \mathrm{M} \mathrm{HCl}$ solution. Solution $\mathrm{pH}$ optimization is required to obtain a high $\mathrm{PD} / \mathrm{CD}$ ratio. This is a very critical and important point in the experimental work. In the present study, the $\mathrm{pH}$ values considered for the treated solutions in the cells were $3,4,5,6,7,8$, and 10. Measurements of each $\mathrm{pH}$ range were recorded after 10 days of operation. The results confirmed that the natural $\mathrm{pH}$ is the optimal condition to reach the maximum voltage. At $\mathrm{pH}$ 7, BMFC-I, BMFC-II, and BMFC-III showed potential values of $120 \mathrm{mV}, 35 \mathrm{mV}$, and $124 \mathrm{mV}$, respectively. At pH 3, BMFC-I, BMFC- II, and BMFC- III has the potential value of $24 \mathrm{mV}, 5 \mathrm{mV}$, and $26 \mathrm{mV}$, respectively. Similarly, at $\mathrm{pH}$ 10, the value was $20 \mathrm{mV}, 9 \mathrm{mV}$, and $44 \mathrm{mV}$ for BMFC-I, BMFCII, and BMFC- III, respectively. The conclusion is that a highly acidic or basic condition disturbs the bacterial growth and damages the biofilm on the anode, which led to the decrease of the potential. 
He et al. (2008) studied the operation of MFC in the pH range of 5-6 and reported low PD. They concluded that natural $\mathrm{pH}$ is a critical condition for producing sufficient voltage. Another study was carried out by Huang et al. (2012) observed the effect of $\mathrm{pH}$ on power density, where they concluded that at $\mathrm{pH} 5.2$, the voltage was low due to the generation of acidic by-products, whereas treatments at natural $\mathrm{pH}$ presented a clear increment in voltage generation. Similarly, Din et al. (2020) also concluded that the neutral $\mathrm{pH}$ is the optimum condition in MFC when using waste material (potatoes waste) as organic substrate. Both extremes in $\mathrm{pH}$ value of the media in the cells, either too acidic or toon alkaline, are not suitable for bacterial growth at which organic waste is used as substrate in BMFC.

\subsection{Effect of the temperature on energy generation in the presence of natural waste in BMFC}

The BMFC were operated at a different temperature range from $15^{\circ} \mathrm{C}$ to $35^{\circ} \mathrm{C}$. The range is slightly higher than room temperature, or slightly lower than room temperature. The objective was to optimize the temperature effect on energy generation in BMFC. Our results indicated that $25^{\circ} \mathrm{C}$ is suitable for BMFC operation to achieve the maximum energy output (Fig. 4b). BMFC-I, BMFC- II, and BMFC- II exhibited a potential value of $45 \mathrm{mV}, 39 \mathrm{mV}$, and $49 \mathrm{mV}$, respectively. All BMFC reactions were observed at $\mathrm{pH} 7$ with $560 \Omega$ external resistances. The measurements were recorded after $24 \mathrm{~h}$ of operation. The temperature range $\left(15-20^{\circ} \mathrm{C}\right)$ that was lower than room temperature led to a very low voltage potential due to the harsh conditions for bacterial growth. All exoelectrogenic bacteria require an optimum condition for growth that also includes a favorable temperature. Another aspect observed is that below $20{ }^{\circ} \mathrm{C}$ there is still a voltage generated, for example, 5-9 mV (BMFC- I), 2-5 mV (BMFC- II), and 5-12 mV (BMFC- III) but at temperatures of $15{ }^{\circ} \mathrm{C}$ and below the survival level of the bacteria is doubtful. 
305
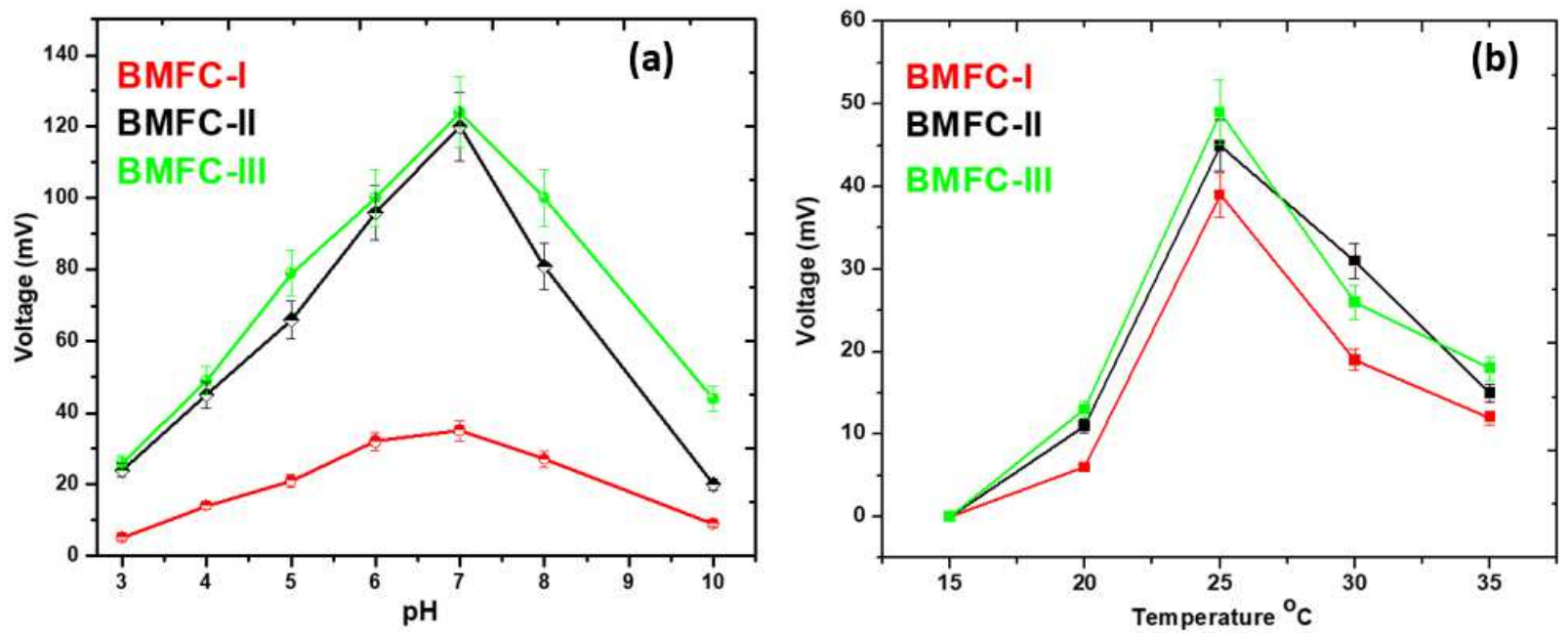

Fig. 4: (a) Effect of $\mathrm{pH}$ (b) effect of temperature on energy generation during BMFC operation.

\subsection{Effect of organic substrate in BMFC}

The organic substrate is the energy source required for the bacterial growth and their respiration process during the $\mathrm{BMFC}$ operation, which leads to the generation of electrons and protons and concurrently pollutant remediation. The organic substrate is one of the most important aspects of all the bioelectrochemical cells because bacteria require fuel for respiration during the oxidation process (Barbosa et al. 2017). To our knowledge, very rarely efforts have been made to use natural waste as an organic substrate in BMFC applications (Fadzli et al. 2021a). Several types of organic substrates such as glucose, protein, carbohydrate, sucrose, fructose, cellulose vegetable waste, and biomass waste have been used in MFC studies (Gezginci \&Uysal 2016, Meshram \&Jadhav 2017, Pant et al. 2010). These natural wastes can be taken as an organic substrate, which is to minimize operating costs if the system is implemented on a large scale.

Salvin et al. (2015) studied mangroves as an organic substrate in BMFC to produce bioenergy and they achieved significant results while controlling operating costs. Unfortunately, there is still a lack of reports reflecting efforts to use natural organic waste in BMFC that allow us to compare our results. Therefore, we have considered reports in which some natural wastes have 
322 been used as organic substrates in MFC to discuss the importance of our work. In this study, the 323 BMFC operation was not given an additional substrate except the waste materials placed at the 324 beginning of the operation. Table 3 shows a comparison of works in which waste materials have 325 been used in several MFC systems.

326 Table 3: Comparison summary of previous reports on waste material and CD outcomes obtained 327 with different organic substrates in MFC.

\begin{tabular}{|c|c|c|c|c|}
\hline $\begin{array}{l}\text { Type of } \\
\text { fuel cell }\end{array}$ & Substrate & Inoculum source & $\begin{array}{l}\text { Current } \\
\text { density } \\
\left(\mathrm{mA} / \mathrm{cm}^{2}\right)\end{array}$ & Reference \\
\hline DMFC & Landfill leachate & $\begin{array}{l}\text { Leachate and } \\
\text { sludge }\end{array}$ & 0.0004 & $\begin{array}{l}\text { (Greenman et al. } \\
\text { 2009) }\end{array}$ \\
\hline DMFC & $\begin{array}{l}\text { Macroalgae, Ulva } \\
\text { lactuca }\end{array}$ & Mixed culture & 0.025 & $\begin{array}{l}\text { (Velasquez-Orta } \\
\text { et al. 2009) }\end{array}$ \\
\hline DMFC & $\begin{array}{l}\text { Malt extract, yeast } \\
\text { extract } \\
\text { and glucose }\end{array}$ & $\begin{array}{l}\text { Pure culture of } E \text {. } \\
\text { cloacae }\end{array}$ & 0.067 & $\begin{array}{l}\text { (Mohan et al. } \\
\text { 2008) }\end{array}$ \\
\hline DMFC & $\begin{array}{l}\text { Microcrystalline } \\
\text { cellulose }\end{array}$ & - & 0.02 & $\begin{array}{l}\text { (Rismani-Yazdi } \\
\text { et al. 2008) }\end{array}$ \\
\hline SMFC & $\begin{array}{l}\text { Brewery } \\
\text { wastewater }\end{array}$ & $\begin{array}{l}\text { Full strength } \\
\text { brewery } \\
\text { wastewater }\end{array}$ & 0.2 & (Feng et al. 2008) \\
\hline SMFC & $\begin{array}{l}\text { Beer brewery } \\
\text { wastewater }\end{array}$ & $\begin{array}{l}\text { Anaerobic mixed } \\
\text { consortia }\end{array}$ & 0.18 & (Wen et al. 2009) \\
\hline
\end{tabular}




\begin{tabular}{lllll}
\hline DMFC & Chocolate industry & Activated sludge & 0.302 & (Patil et al. 2009) \\
& wastewater & & & \\
BMFC & Rambutan waste & Synthetic & 0.0036 & Present work \\
& & wastewater & & \\
BMFC & Langsat waste & Synthetic & 0.029 & Present work \\
& & wastewater & & \\
BMFC & Mango waste & Synthetic & 0.0087 & Present work \\
& & wastewater & &
\end{tabular}

$\mathrm{DMFC}=$ Double chamber microbial fuel cell; $\mathrm{SMFC}=$ Single chamber microbial fuel cell; $\mathrm{BMFC}=$ Benthic microbial fuel cell

\subsection{Removal of toxic metals from synthetic wastewater through BMFC}

The potential in the BMFC was generated through electrons flow, these electrons were released from the anode because of the oxidation and reduction of metals in the anodic chamber. The electrons were transferred to the cathode electrode through the external resistance and therefore, the removal of the metal may be related in a positive way to the energy generation (Serrà et al. 2021). The wastewater that was used in the present work was spiked with $\mathrm{Cd}^{2+}$ and $\mathrm{Pb}^{2+}$. The detected concentrations of metal during and at the end of the operation are summarized in Table 4. At the beginning of the BMFC operation, the concentration of metals (50 ppm) was considered as the initial concentration and after the operation of the cells, the final metal concentration of the metals allowed the calculation of the metal removal. According to Table 4, BMFC-III showed an excellent removal efficiency of $\mathrm{Cd}^{2+}$ and $\mathrm{Pb}^{2+}$. The highest removal efficiency of $\mathrm{Cd}^{2+}$ and $\mathrm{Pb}^{2+}$ was $78 \%$ and $80 \%$, respectively after $40-45$ days of operation. Similarly, BMFC-II showed the lowest performance in terms of removal of $\mathrm{Cd}^{2+}$ and $\mathrm{Pb}^{2+}$ than BMFC-III. All the BMFC were 
343 performed with the same parameters, usually, a low redox potential is required for metal removal.

344 Out of the three systems, the BMFC-III presented the best results because the organic substrate

345 (mango waste) provides enough energy to bacteria for survival in a highly toxic environment,

346 which efficiently promotes the removal of metals. It was observed that over time, the performance

347 of the cell (catalyzed by the bacteria) was affected due to the consumption of substrate. The

348 constant supply of organic substrates as fuel for bacteria remains a challenge in BMFC. The short-

349 term availability of fuel cells limits the performance of BMFC for its use on an industrial scale.

350 Table 4: Removal trend of targeted metals via BMFC in the presence of different organic

351 substrates.

\begin{tabular}{|c|c|c|c|c|c|c|c|}
\hline \multirow{3}{*}{$\begin{array}{l}\text { MFC } \\
\text { reactors }\end{array}$} & \multirow{3}{*}{$\begin{array}{l}\text { Organic } \\
\text { substrate }\end{array}$} & \multirow{3}{*}{$\begin{array}{l}\text { Incubation } \\
\text { media }\end{array}$} & \multirow{3}{*}{$\begin{array}{l}\text { Initial } \\
\text { concentratio } \\
\mathrm{n}(\mathrm{ppm})\end{array}$} & \multirow{2}{*}{$\begin{array}{l}\text { Target } \\
\text { pollutant }\end{array}$} & \multirow{3}{*}{$\begin{array}{l}\text { Operational } \\
\text { time } \\
\text { (Days) }\end{array}$} & \multirow{2}{*}{$\begin{array}{l}\text { Removal } \\
\text { efficiency }\end{array}$} & \multirow{4}{*}{$\begin{array}{l}\text { Removal } \\
\text { efficiency } \\
(\%) \text { of } \mathrm{Pb}^{2+}\end{array}$} \\
\hline & & & & & & & \\
\hline & & & & & & $(\%)$ & \\
\hline & & & & & & $\mathrm{Cd}^{2+}$ & \\
\hline $\mathrm{BMF}$ & Rambuta & Synthetic & 50 & $\mathrm{Cd}^{2+} \&$ & 0 & 0 & 0 \\
\hline \multirow[t]{5}{*}{ C-I } & $\mathrm{n}$ & wastewater & & $\mathrm{Pb}^{2+}$ & 10 & 13 & 16 \\
\hline & & & & & 20 & 28 & 26 \\
\hline & & & & & 30 & 40 & 39 \\
\hline & & & & & 40 & 49 & 50 \\
\hline & & & & & 45 & 60 & 68 \\
\hline \multirow[t]{3}{*}{ BMFC-II } & Langsat & Synthetic & 50 & $\mathrm{Cd}^{2+} \quad \&$ & 0 & 0 & 0 \\
\hline & & wastewater & & $\mathrm{Pb}^{2+}$ & 10 & 5 & 6 \\
\hline & & & & & 20 & 21 & 22 \\
\hline
\end{tabular}


BMFC- Mango Synthetic 50

III wastewater
30

40

45
32

58

69

0

16

31

42

65

78

$(8$

35

60

71

0

18

29

44

69

45

0

80
352

353

354

355

356

357

358

359

360

361

362

363

364

\subsection{Effect of $\mathrm{pH}$ on metal removal from synthetic wastewater}

The $\mathrm{pH}$ effect on the removal efficiency of $\mathrm{Cd}^{2+}$ and $\mathrm{Pb}^{2+}$ were clearly observed, and it is shown in Fig. 5a. In all BMFC setups, the $\mathrm{pH}$ was adjusted by using $1 \mathrm{M} \mathrm{NaOH}$ and $1 \mathrm{M} \mathrm{HCl}$ solutions and the removal efficiency at each $\mathrm{pH}$ was recorded after 10 days of operation. The results showed that as $\mathrm{pH}$ increases from 3 to 10 , a clear removal percentage (\%) was observed.

Out of the three systems, the BMFC-III presented quite significant removal efficiency within 10 days for $\mathrm{Cd}^{2+}$ and $\mathrm{Pb}^{2+}$, i.e., $20 \%$ and $22 \%$, respectively at $\mathrm{pH} 7$. These were the highest percentages of removal observed. BMFC-I, BMFC-II also showed the highest removal efficiency at $\mathrm{pH} 7$ compared to other $\mathrm{pH}$ ranges. On the contrary, $\mathrm{pH} 3$ was a highly acidic condition and $\mathrm{pH}$ 10 was a highly alkaline condition, where both conditions were not favorable for bacterial growth.

Neutral $\mathrm{pH}$ increases the high removal efficiency due to the diffusion of $\mathrm{H}+$ ions from the cathodic 
to the anodic space as the $\mathrm{pH}$ decreases. The acidic anodic environment has a negative impact on bacterial activity, especially inhibiting growth as well as oxidation/reduction processes.

\section{Effect of temperature on metals removal from synthetic wastewater}

BMFC- I, BMFC- II and BMFC- III were operated at different temperatures of $15^{\circ} \mathrm{C}$ to $35^{\circ} \mathrm{C}$ for the removal of $\mathrm{Cd}^{2+}$ and $\mathrm{Pb}^{2+}$ (Fig. 5 b). Out of the three, BMFC- III showed the highest removal efficiencies of $15.8 \%$ and $18.2 \%$ for $\mathrm{Cd}^{2+}$ and $\mathrm{Pb}^{2+}$, respectively, at room temperature. In all the BMFC, as temperature increased from $15^{\circ} \mathrm{C}$, the removal efficiency increased slowly. All the BMFC showed the highest removal efficiency at $25^{\circ} \mathrm{C}$ and the lowest removal efficiency at $15^{\circ} \mathrm{C}$. The temperatures of $15^{\circ} \mathrm{C}$ and $35^{\circ} \mathrm{C}$ are not favorable for bacteria survival. Most of the bacteria start the decay phase at temperatures above $35^{\circ} \mathrm{C}$ or below $20^{\circ} \mathrm{C}$. Some bacteria can survive above $35^{\circ} \mathrm{C}$ under optimized and controlled conditions (Lechevallier et al. 1988). At lower and higher temperature ranges, the rate of toxic metal removal becomes low. At room temperature, the removal rate increases due to a decrease in ohmic resistance, an increase in metabolic pathways, and greater water conductivity. The temperature and ohmic resistance, both are inversely proportional. As ohmic resistance increase, the temperature will be lower and vice versa due to conductive stability of metal ions. However, the ohmic resistance variation is not only restricted to fluctuations in the temperature range. Out of all the systems, the BMFC- III showed the maximum removal rate because bacteria tended to thrive in this system due to a sufficient supply of energy in form of organic substrate. The other systems (BMFC-I and BMFC- II), however, failed to supply sufficient energy for bacterial activity during their operations. 

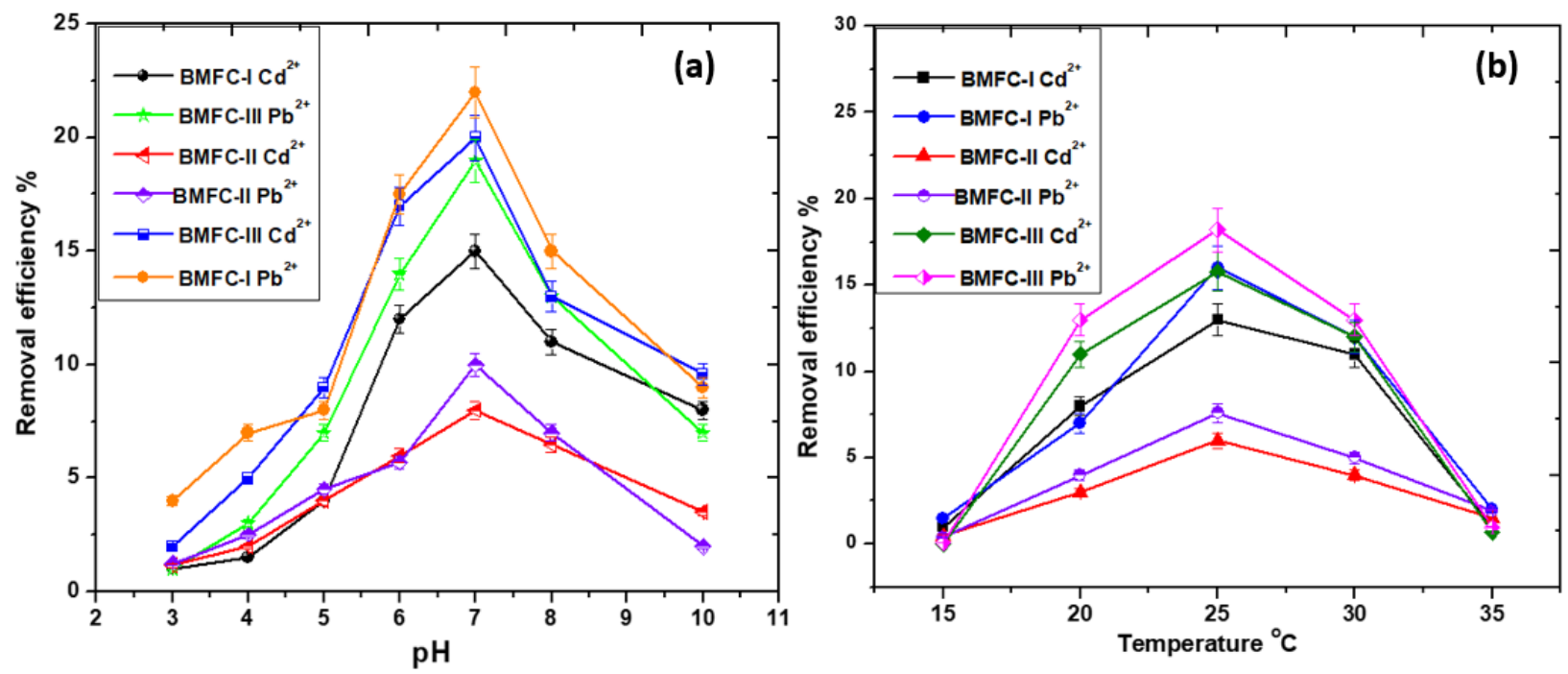

385

386

387

388

Fig. 5: (a) Effect of $\mathrm{pH}$ (b) effect of temperature on the removal of metals from synthetic wastewater

\subsection{Biofilm analyses and operational mechanism of BMFC}

The biofilm formed on the surface of the anode is well known as a niche of microbes. The presence of bacteria species on the surface of the anodes was responsible for the reduction of metal as well as generating the energy output. Fig. 6 (a-f) shows the SEM images of the anodes without biofilm and with biofilm after successful operation of BMFC-I, BMFC-II and BMFC-III. The SEM images (Fig. 6 a, c, e) clearly showed that the fresh anode (before the operation starts) does not show any kind of bacterial species present on surface. After the operation, it was observed that BMFC-III showed a larger bacterial species on the used anode surface than BMFC-I or BMFC-II. Unfortunately, BMFC-II shows a very dense bacterial population but differs greatly in quantity with BMFC-I and BMFC-III. BMFC-I and BMFC-III show some filament rod structure in SEM image, BMFC-III also shows clear filament rod structure. There are several SEM analytical studies on biofilms, but rarely report the presence of filament rod structures on the anode surface (Reimers et al. 2017, Xu et al. 2016) . These discrepancies may be due to different operating conditions, especially at the source of the inoculum or altered system parameters such as $\mathrm{pH}$ and temperature. 

are responsible for electron transfer.
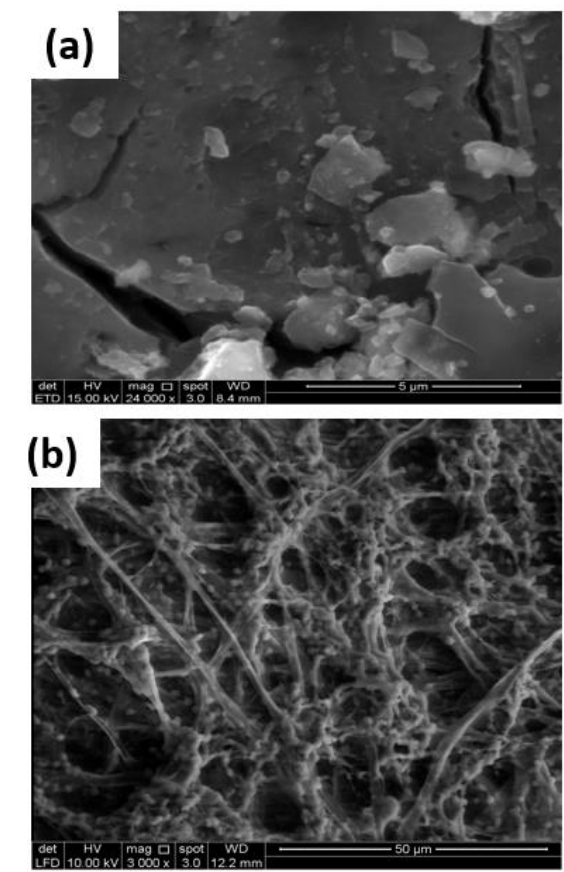

Organic or inorganic substrates are also important factors influencing bacterial activity. In the present work, it was observed that exoelectrogens species are showing the filamentous rod structures to transfer the electrons to anode electrode. Generally, the Shewanella or Geobacter species utilize conductive pili to transfer the electrons (Yaqoob et al. 2020b). Based on SEM images obtained from BMFC- I, BMFC- II, and BMFC- III, it can be concluded that rod-like wires
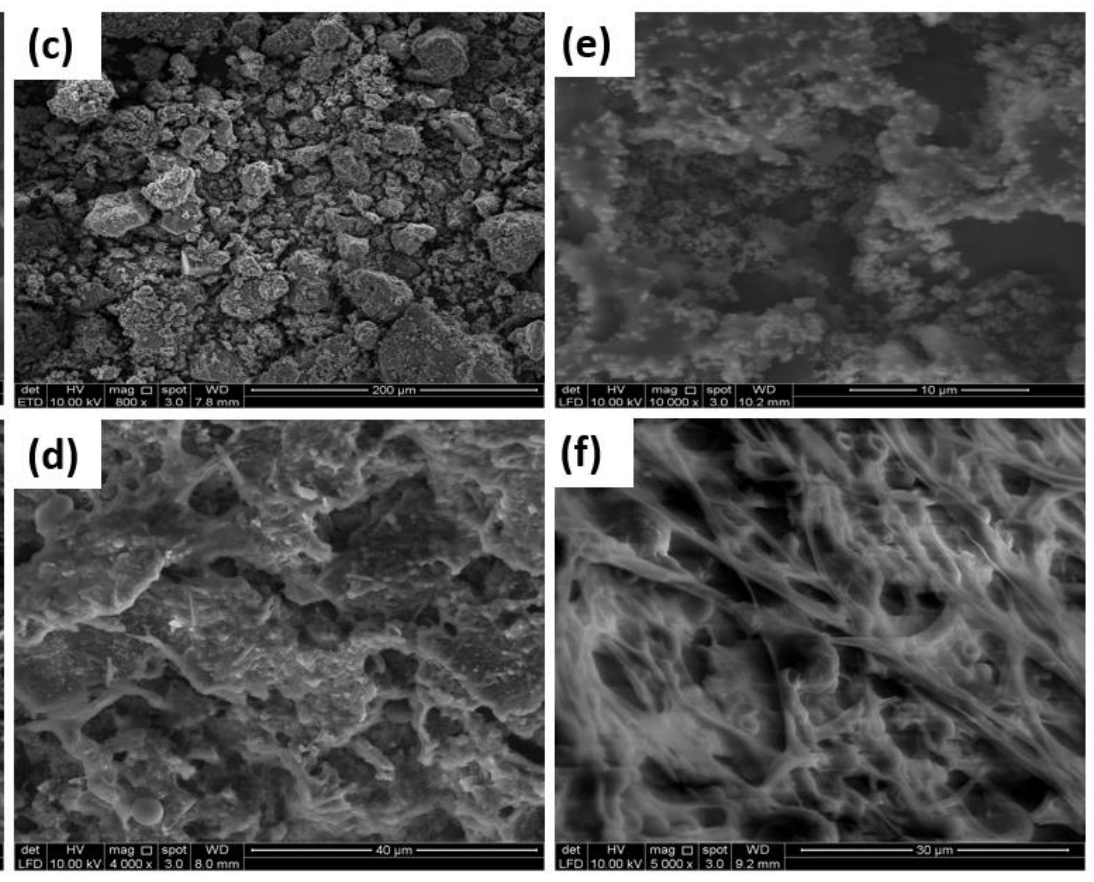

Fig. 6: Biofilm morphology on the anode of (a-b) Fresh and used anode of BMFC-I (c-d) Fresh and used anode of BMFC-II (e-f) Fresh and used anode of BMFC- III.

The energy generation and electron transfer mechanisms are key factors to initiate the removal process of metal ions. In BMFC, the organic substrate is oxidized by bacterial species which generate electrons and protons during their respiration. Several exoelectrogens are well known in MFC field as energy generators (through transferring electrons) while simultaneously diminishing the metals concentration. Some examples of these bacterial are Geobacter sp. Klebsiella pneumoniae, Acinetobacter, Shewanella sp. and Proteus sp. etc. (Chuo et al. 2020, Yaqoob et al. 
417 2020b). In the present study, during the BMFC operation, the bacterial species produced a biofilm

418 (a sludge around the anode electrode), which serves as a source of microorganisms to transfer the 419 electrons to the anode electrode from bacteria. The electrons and protons are produced by bacterial 420 species during the oxidation process of organic substrate (Franks \&Nevin 2010). This process was 421 completed through the Kreb cycle mechanism that occurs inside the bacterial species. Chai et al. 422 (Chai et al. 2018) reported that rambutan contains a maximum of $10.01 \%$ (sucrose), $3.18 \%$ 423 (fructose) and $2.43 \%$ (simple sugar) and other carbohydrate content. Similarly, several studies 424 showed that, mango and langsat also present a high sugar content (Arumugam \&Manikandan 2011, 425 Sudha et al. 2015, Techavuthiporn 2018). The organic substrate derived from this waste is sugar426 based; therefore, they are believed to be efficient in promoting bacterial growth and the respiratory 427 process. In order for these organic substrates to function as a source of carbon and energy, the

428 conversion of complex sugars into a more moderate form (i.e., glucose) must be performed. Glucose can be further oxidized by bacterial species on the anode surface. The oxidation process can be written as:

$$
\begin{aligned}
& \text { Anode: } \mathrm{C}_{6} \mathrm{H}_{12} \mathrm{O}_{6}+6 \mathrm{H}_{2} \mathrm{O} \longrightarrow 6 \mathrm{CO}_{2}+24 \mathrm{H}^{+}+24 \mathrm{e}^{-} \\
& \text {Cathode: } 24 \mathrm{H}^{+}+24 \mathrm{e}^{-}+6 \mathrm{O}_{2} \longrightarrow 12 \mathrm{H}_{2} \mathrm{O} \\
& \text { Overall reaction: } \mathrm{C}_{6} \mathrm{H}_{12} \mathrm{O}_{6}+6 \mathrm{O}_{2} \longrightarrow 6 \mathrm{CO}_{2}+6 \mathrm{H}_{2} \mathrm{O}+\text { Electricity }
\end{aligned}
$$

The electrons produced during the oxidation are transferred to the anode via different mechanisms, in turn, these electrons are transferred via outer circuit. The produced protons are moved towards the cathode electrode through proton exchange membrane (Yaqoob et al. 2020a). Usually, two major type of electron transfer mechanisms are present which are following (Fig. 7):

- Direct electron transfer, which is carried out through the conductive pili (this is a filamentous wire shape that is part of some bacterial species) and redox-active proteins 
454 follows:

$455 \quad-\quad$ Conversion of $\mathrm{Cd}^{2+}$ to $\mathrm{Cd}_{(\mathrm{s})}$

$456 \mathrm{Cd}^{2+}+2 \mathrm{e}^{-} \longrightarrow \mathrm{Cd}_{(\mathrm{s})}$

$4572 \mathrm{Cd}^{2+}+2 \mathrm{H}_{2} \mathrm{O} \longrightarrow 2 \mathrm{CdO}+4 \mathrm{H}^{+}$

$458 \mathrm{CdO}+2 \mathrm{e}^{-}+2 \mathrm{H}^{+} \longrightarrow \mathrm{Cd}_{(\mathrm{s})}+\mathrm{H}_{2} \mathrm{O}$

$459 \quad-\quad$ Conversion of $\mathrm{Pb}^{2+}$ to $\mathrm{Pb}_{(\mathrm{s})}$

$460 \mathrm{~Pb}^{2+}+2 \mathrm{e}^{-} \longrightarrow \mathrm{Pb}_{(\mathrm{s})}$

$4612 \mathrm{~Pb}^{2+}+2 \mathrm{H}_{2} \mathrm{O} \longrightarrow 2 \mathrm{PbO}+4 \mathrm{H}^{+}$

$462 \mathrm{PbO}+2 \mathrm{e}^{-}+2 \mathrm{H}^{+} \longrightarrow \mathrm{Pb}_{(\mathrm{s})}+\mathrm{H}_{2} \mathrm{O}$ 


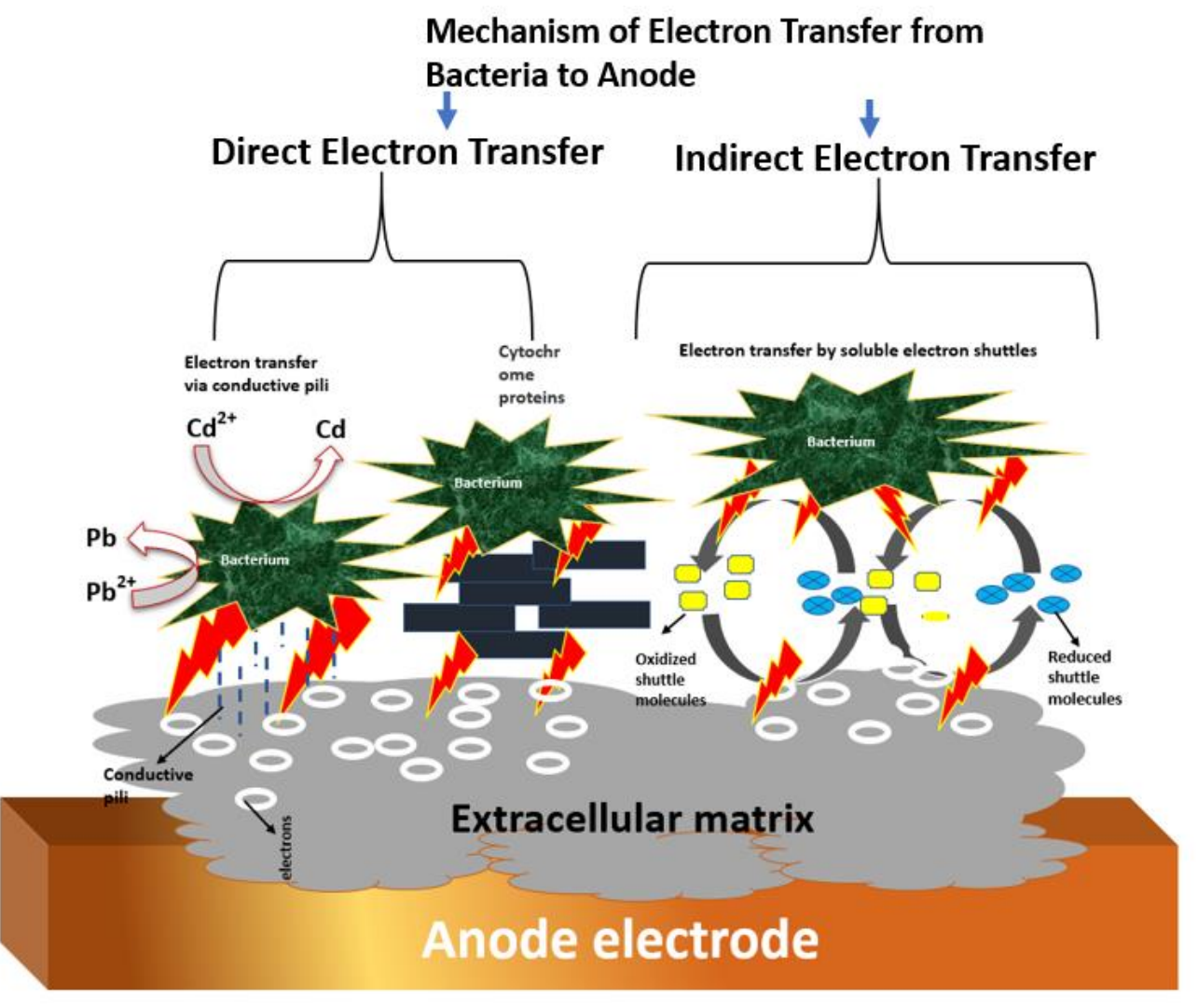

Fig. 7: Different electron transfer mechanisms during the BMFC operation.

\subsection{Bacterial isolation and identification studies}

The anodic biofilms of BMFC-I, BMFC-II, and BMFC-III were further analyzed through isolation and bacterial identification processes. Table 5 shows the list of the exoelectrogens that were extensively present on the surface of the BMFC-I, BMFC-II, and BMFC-III anodes. According to the observed results, almost identical bacterial species were found on the anode surfaces of BMFCI, BMFC-II, and BMFC-III. The SEM images of the used anode also confirmed that there were a small number of bacterial species. A large number of bacteria have a filamentous structure, which suggested that conductive pili were responsible for electron transfer. The BMFC-II biofilm showed a dense bacterial population, and several different species were detected which were different from those detected on other cells. These differences may be due to environmental factors. BMFC-I and BMFC-III showed fewer bacterial species but have similar morphology. The observed bacterial 
476 species such as Klebsiella pneumoniae, Citrobacter amalonaticus and Enterobacter species are 477 well known as exoelectrogens species (Kumar et al. 2021, Munoz-Cupa et al. 2020, Wang et al. 478 2020, Yaqoob et al. 2020b, Zhang et al. 2020). For example, Zhang et. al., (2008) reported that 479 Klebsiella pneumoniae is one of the most efficient exoelectrogens in MFC and that the maximum 480 achieved power density obtained when this bacteria was present was of $151.11 \mathrm{~mW} / \mathrm{m}^{2}$. They 481 stated that Klebsiella pneumoniae were responsible for electrons transfer through conductive pili. 482 Uddin et al., (2020) carried out an extensive review about the metal reduction through bacterial 483 species and they mentioned that Klebsiella pneumoniae, Enterobacter, and Citrobacter were 484 metal-reducing bacterial species. According to these evidences it can be proposed that the bacterial 485 species that were identified in the present work were responsible for electricity generation and 486 removal of metal ions from the synthetic wastewater.

487 Table 5: The identified bacteria species from the anodic biofilms of BMFC-I, BMFC-II and 488 BMFC-III.

\begin{tabular}{|c|c|c|c|}
\hline \multirow[t]{2}{*}{ Bacteria } & Accession number1(6S & Query & Identity $(\%)$ \\
\hline & rRNA Gene) & cover & \\
\hline
\end{tabular}

\section{BMFC-I}

Klebsiella pneumoniae subsp. NR_037084.1 rhinoscleromatis strain $R-70$

$\begin{array}{llll}\text { Klebsiella pneumoniae strain } \quad \text { NR_119278.1 } & 9870\end{array}$ ATCC 13883 


\begin{tabular}{|c|c|c|c|}
\hline $\begin{array}{l}\text { Pseudocitrobacter faecalis } \\
\text { strain } 25 \text { CIT } 1\end{array}$ & NR_125690.1 & 98 & 97.70 \\
\hline $\begin{array}{l}\text { Citrobacter amalonaticus } \\
\text { strain CECT } 863\end{array}$ & NR_104823.1 & 98 & 98.21 \\
\hline Kosakonia sacchari strain & NR_118333.1 & 98 & 98.20 \\
\hline$S P 1$ & & & \\
\hline $\begin{array}{l}\text { Citrobacter amalonaticus } \\
\text { strain LMG } 7873\end{array}$ & NR_118106.1 & 97 & 96.25 \\
\hline Kluyvera ascorbata ATCC & NR_114589.1 & 96 & 98.05 \\
\hline 33433 & & & \\
\hline Providencia sneebia DSM & NR_104913.1 & 98 & 97.24 \\
\hline 19967 & & & \\
\hline Pantoea dispersa strain $L M G$ & & 98 & 97.20 \\
\hline 2603 & NR_116755.1 & & \\
\hline Kosakonia radicincitans DSM & NR_117704.1 & 98 & 97.24 \\
\hline 16656 & & & \\
\hline Klebsiella oxytoca strain & NR_114152.1 & 98 & 97.07 \\
\hline NBRC 102593 & & & \\
\hline
\end{tabular}




\section{BMFC-II}

Klebsiella quasipneumoniae

NR_134062.1

subsp. quasipneumoniae

strain $01 A 030$

Klebsiella pneumoniae strain NR_036794.1

DSM 30104

Enterobacter cloacae subsp. $\quad$ NR_118011.

dissolvens strain ATCC

Enterobacter cloacae subsp.

NR_044978.1

98

98.05

dissolvens strain LMG 2683

Citrobacter farmeri strain

CDC 2991-81

Raoultella planticola ATCC

NR_024996.1

96

97.84

33531

BMFC-III

98

98.54

98

97.88

98

98.06

98

97.21

NR_024861.1

(1)




\begin{tabular}{|c|c|c|c|}
\hline $\begin{array}{l}\text { Klebsiella pneumoniae strain } \\
\text { JCM1662 }\end{array}$ & NR_112009.1 & 98 & 97.70 \\
\hline $\begin{array}{l}\text { Citrobacter freundii strain } \\
\text { NBRC } 12681\end{array}$ & NR_113596.1 & 98 & 97.40 \\
\hline $\begin{array}{l}\text { Raoultella planticola ATCC } \\
33531\end{array}$ & NR_119279.1 & 98 & 97.73 \\
\hline $\begin{array}{l}\text { Yokenella regensburgei strain } \\
\text { CIP }\end{array}$ & NR_104934.1 & 98 & 97.70 \\
\hline $\begin{array}{l}\text { Kluyvera intermedia strain } \\
256\end{array}$ & NR_028802.1 & 98 & 97.72 \\
\hline $\begin{array}{l}\text { Serratia marcescens subsp. } \\
\text { marcescens ATCC } 13880\end{array}$ & NR_041980.1 & 98 & 97.56 \\
\hline $\begin{array}{l}\text { Gibbsiella dentisursi strain } \\
\text { LEN33 }\end{array}$ & NR_118387.1 & 98 & 97.72 \\
\hline
\end{tabular}
4. Conclusion, future challenges, and perspectives BMFC opened a new door of research in the field of microbial fuel cells that may positively 493 lead to an environmentally friendly, sustainable, easily controllable, and cost-effective approach 494 to energy generation and wastewater treatment. Increasing evidence has been developed in recent 
years to demonstrate the BMFC significance for improving the natural bioremediation practices. BMFC still needs attention to perform at a larger scale due to several challenges. According to the literature review, it was observed that most of the efforts have been focused on development of electrodes in BMFC to enhance the energy output or improving bioremediation process. In BMFC the performance of the electrodes is an important aspect but there are other important aspects that must be considered for a successful BMFC performance, i.e., organic substrate or waste used in the BMFC as fuel for bacterial activities. In the present work, the focus is on the organic substrate, which is well known as a fuel for bacteria species to generate the energy in the BMFC, which leads to a successful green technology. The present study targeted three local Malaysian fruit wastes which are available in large amounts in the country as well as several other Southeast Asia nations. The utilization of waste material as organic substrate was an ideal approach to generate bioenergy and toxic metals removal. Currently, Malaysia faces the problem of the presence of toxic metals in water resources, especially the presence of $\mathrm{Cd}^{2+}$ and $\mathrm{Pb}^{2+}$.

The operation of the system in this work was performed in three separate but identical preparations for 45 days until the bacterial species entered the decaying phase due to insufficient energy supply. The maximum CD produced in BMFC-I, BMFC-II and BMFC-III was of 36.84 $\mathrm{mA} / \mathrm{m}^{2}, 39.47 \mathrm{~mA} / \mathrm{m}^{2}$ and $87.71 \mathrm{~mA} / \mathrm{m}^{2}$, respectively. These values were achieved by varying the different external resistances from $150-7 \mathrm{k} \Omega$. Out of the three fruit wastes, the mango waste (peel and seed waste) was the preferred as fuel for bacteria due to the presence of a high sugar content. The sugar content is the energy source for bacterial growth and respiration. Similarly, the removal efficiency of $\mathrm{Cd}^{2+}$ and $\mathrm{Pb}^{2+}$ were also successfully achieved. The BMFC-I presented $60 \%\left(\mathrm{Cd}^{2+}\right)$ and $68 \%\left(\mathrm{~Pb}^{2+}\right)$ removals, BMFC- II presented $69 \%\left(\mathrm{Cd}^{2+}\right)$ and $71 \%\left(\mathrm{~Pb}^{2+}\right)$ removals and BMFCIII presented $78 \%\left(\mathrm{Cd}^{2+}\right)$ and $80 \%\left(\mathrm{~Pb}^{2+}\right)$ removals. According to the experimental outcomes 
518 obtained on the energy generation and metals removal, it was important to optimize the $\mathrm{pH}$ and 519 temperature. It was found that the neutral $\mathrm{pH}$ and room temperature are the most favorable 520 conditions to create an environment for biofilm growth and promoting metabolic activities.

521 According to present observations, it manages to produce a reasonable energy output in a 522 relatively short time compared to the previous works, but its metal removal rate is relatively low.

523 The reason for the low removal efficiency is the instability of the fruit waste for long periods of 524 time. Decreased waste causes a decrease in energy supply over time which affects bacterial 525 activity. Therefore, future research should be done on different wastes that can provide long-term energy supply to bacteria for more effective removal efficiency. Different waste materials such as sugar cane waste, durian (durio) waste, potatoes waste etc. are expected to address the long-term energy supply issue. Research on the production of efficient electrodes and organic substrates for BMFC could result in better metal removal efficiencies. Metal removal is almost never studied in BMFC compared to sedimentary microbial fuel cells or MFC. Thus, promoting the use of BMFC as a safe and green approach requires a comprehensive and continuous effort.

\section{Author contribution}

Mohamad Nasir Mohamad Ibrahim, Khalid Umar: Conceptualization. Asim Ali Yaqoob, Khalid

535 electromicrobiology investigation. Claudia Guerrero-Barajas: English editing of the manuscript.

536 Mohamad Nasir Mohamad Ibrahim: Supervision, funding acquisition. This article has been read 537 and approved by all listed authors.

538 Acknowledgments

539 This research article was financially supported by Universiti Sains Malaysia, (Malaysia) under the 540 Research Grant; 304/PKIMIA/6501153/E128. 


\section{Data Availability Statement}

542 The authors confirm that all data underlying the findings are fully available without restriction.

543 Data can be obtained after submitting a request to the corresponding/first author.

\section{Declarations}

545

Ethics approval and consent to participate: Not applicable.

546 Consent for publication: Not applicable.

547 Competing interests: The authors declare no competing interests.

548

549

550

551

552

553

554

555

556

557

558

559

560

\section{References:}

Arumugam R, Manikandan M (2011): Fermentation of pretreated hydrolyzates of banana and mango fruit wastes for ethanol production. Asian J. Exp. Biol. Sci 2, 246-256

Asim AY, Mohamad N, Khalid U, Tabassum P, Akil A, Lokhat D, Siti H (2021): A glimpse into the microbial fuel cells for wastewater treatment with energy generation. Desalination and Water Treatment 214, 379-389

Barbosa SG, Peixoto L, Ter Heijne A, Kuntke P, Alves M, Pereira MA (2017): Investigating bacterial community changes and organic substrate degradation in microbial fuel cells operating on real human urine. Environmental Science: Water Research \& Technology 3, 897-904

Chai KF, Adzahan NM, Karim R, Rukayadi Y, Ghazali HM (2018): Selected physicochemical properties of registered clones and wild types rambutan (Nephelium lappaceum L.) fruits and their potentials in food products. Sains Malaysiana 47, 1483-1490 
Chen S, He G, Carmona-Martinez AA, Agarwal S, Greiner A, Hou H, Schröder U (2011): Electrospun carbon fiber mat with layered architecture for anode in microbial fuel cells. Electrochemistry communications 13, 1026-1029

Chen W, Liu Z, Su G, Fu Y, Zai X, Zhou C, Wang J (2017): Composite-modified anode by $\mathrm{MnO} 2 /$ polypyrrole in marine benthic microbial fuel cells and its electrochemical performance. International Journal of Energy Research 41, 845-853

Chuo SC, Mohamed SF, Mohd Setapar SH, Ahmad A, Jawaid M, Wani WA, Yaqoob AA, Mohamad Ibrahim MN (2020): Insights into the current trends in the utilization of bacteria for microbially induced calcium carbonate precipitation. Materials 13, 4993

Daud NNM, Ahmad A, Yaqoob AA, Ibrahim MNM (2021): Application of rotten rice as a substrate for bacterial species to generate energy and the removal of toxic metals from wastewater through microbial fuel cells. Environmental Science and Pollution Research, $1-12$

Din MI, Iqbal M, Hussain Z, Khalid R (2020): Bioelectricity generation from waste potatoes using single chambered microbial fuel cell. Energy Sources, Part A: Recovery, Utilization, and Environmental Effects, 1-11

Fadzli FS, Bhawani SA, Adam Mohammad RE (2021a): Microbial Fuel Cell: Recent Developments in Organic Substrate Use and Bacterial Electrode Interaction. Journal of Chemistry 2021

Fadzli FS, Rashid M, Yaqoob AA, Ibrahim MNM (2021b): Electricity generation and heavy metal remediation by utilizing yam (Dioscorea alata) waste in benthic microbial fuel cells (BMFCs). Biochemical Engineering Journal 172, 108067 
Feng Y, Wang X, Logan BE, Lee H (2008): Brewery wastewater treatment using air-cathode microbial fuel cells. Applied microbiology and biotechnology 78, 873-880

Franks AE, Nevin KP (2010): Microbial fuel cells, a current review. Energies 3, 899-919

Gezginci M, Uysal Y (2016): The Effect of different substrate sources used in microbial fuel cells on microbial community. JSM Environ Sci Ecol 4, 1035

Greenman J, Gálvez A, Giusti L, Ieropoulos I (2009): Electricity from landfill leachate using microbial fuel cells: comparison with a biological aerated filter. Enzyme and Microbial Technology 44, 112-119

He Z, Huang Y, Manohar AK, Mansfeld F (2008): Effect of electrolyte $\mathrm{pH}$ on the rate of the anodic and cathodic reactions in an air-cathode microbial fuel cell. Bioelectrochemistry 74, 78-82

Huang L, Chai X, Quan X, Logan BE, Chen G (2012): Reductive dechlorination and mineralization of pentachlorophenol in biocathode microbial fuel cells. Bioresource technology 111, 167-174

Joiner KL, Tukeman GL, Obraztsova AY, Arias-Thode YM (2020): Impact of sediment parameters in the prediction of benthic microbial fuel cell performance. RSC Advances 10, $26220-26228$

Kumar B, Agrawal K, Verma P (2021): Microbial Electrochemical System: A Sustainable Approach for Mitigation of Toxic Dyes and Heavy Metals from Wastewater. Journal of Hazardous, Toxic, and Radioactive Waste 25, 04020082

Lechevallier MW, Cawthon CD, Lee RG (1988): Factors promoting survival of bacteria in chlorinated water supplies. Applied and environmental microbiology 54, 649-654 
Li M, Zhou M, Tian X, Tan C, McDaniel CT, Hassett DJ, Gu T (2018): Microbial fuel cell (MFC) power performance improvement through enhanced microbial electrogenicity. Biotechnology advances 36, 1316-1327

Logan BE, Hamelers B, Rozendal R, Schröder U, Keller J, Freguia S, Aelterman P, Verstraete W, Rabaey K (2006): Microbial fuel cells: methodology and technology. Environmental science \& technology $40,5181-5192$

Logan BE (2009): Exoelectrogenic bacteria that power microbial fuel cells. Nature Reviews Microbiology 7, 375-381

Meshram R, Jadhav SK (2017): Bioelectricity Production and Comparative Evaluation of Electrode Materials in Microbial Fuel Cells Using Indigenous Anode-Reducing Bacterial Community from Wastewater of Rice-Based Industries. International Journal of Renewable Energy Development 6

Mohan Y, Kumar SMM, Das D (2008): Electricity generation using microbial fuel cells. International Journal of Hydrogen Energy 33, 423-426

Munoz-Cupa C, Hu Y, Xu CC, Bassi A (2020): An overview of microbial fuel cell usage in wastewater treatment, resource recovery and energy production. Science of the Total Environment, 142429

Nielsen ME, Reimers CE, Stecher HA (2007): Enhanced power from chambered benthic microbial fuel cells. Environmental Science \& Technology 41, 7895-7900

Pant D, Van Bogaert G, Diels L, Vanbroekhoven K (2010): A review of the substrates used in microbial fuel cells (MFCs) for sustainable energy production. Bioresource technology $101,1533-1543$ 
Patil SA, Surakasi VP, Koul S, Ijmulwar S, Vivek A, Shouche Y, Kapadnis B (2009): Electricity generation using chocolate industry wastewater and its treatment in activated sludge based microbial fuel cell and analysis of developed microbial community in the anode chamber. Bioresource technology 100, 5132-5139

Pushkar P, Mungray AK (2020): Exploring the use of 3 dimensional low-cost sugar-urea carbon foam electrode in the benthic microbial fuel cell. Renewable Energy 147, 2032-2042

Rajeswari S, Vidhya S, Krishnaraj RN, Saravanan P, Sundarapandiyan S, Maruthamuthu S, Ponmariappan S, Vijayan M (2016): Utilization of soak liquor in microbial fuel cell. Fuel $181,148-156$

Reimers C, Girguis P, Stecher H, Tender L, Ryckelynck N, Whaling P (2006): Microbial fuel cell energy from an ocean cold seep. Geobiology 4, 123-136

Reimers CE, Li C, Graw MF, Schrader PS, Wolf M (2017): The identification of cable bacteria attached to the anode of a benthic microbial fuel cell: evidence of long distance extracellular electron transport to electrodes. Frontiers in microbiology 8, 2055

Rismani-Yazdi H, Carver SM, Christy AD, Tuovinen OH (2008): Cathodic limitations in microbial fuel cells: an overview. Journal of Power Sources 180, 683-694

Salvin P, Ondel O, Roos C, Robert F (2015): Energy harvest with mangrove benthic microbial fuel cells. International Journal of Energy Research 39, 543-556

Serrà A, Ibrahim MNM, Yaakop AS (2021): Self-assembled oil palm biomass-derived modified graphene oxide anode: An efficient medium for energy transportation and bioremediating Cd (II) via microbial fuel cells. Arabian Journal of Chemistry 14, 103121 
647 Sudha M, Indumathi K, Sumanth M, Rajarathnam S, Shashirekha M (2015): Mango pulp fibre

648

649

650

651

652

653

654

655

656

657

658

659

660

661

662

663

664

665

666

667

668

669

waste: characterization and utilization as a bakery product ingredient. Journal of Food Measurement and Characterization 9, 382-388

Tang J, Liu T, Yuan Y, Zhuang L (2014): Effective control of bioelectricity generation from a microbial fuel cell by logical combinations of $\mathrm{pH}$ and temperature. The Scientific World Journal 2014

Tavakolian M, Taleghani HG, Khorshidian M (2020): New design of benthic microbial fuel cell for bioelectricity generation: Comparative study. International Journal of Hydrogen Energy $45,23533-23542$

Techavuthiporn C (2018): Langsat_Lansium domesticum, Exotic Fruits. Elsevier, pp. 279-283

Uddin MJ, Jeong Y-K, Lee W (2020): Microbial fuel cells for bioelectricity generation through reduction of hexavalent chromium in wastewater: A review. International Journal of Hydrogen Energy

Umar MF, Abbas SZ, Mohamad Ibrahim MN, Ismail N, Rafatullah M (2020): Insights into advancements and electrons transfer mechanisms of electrogens in benthic microbial fuel cells. Membranes 10, 205

Umar MF, Rafatullah M, Abbas SZ, Mohamad Ibrahim MN, Ismail N (2021): Advancement in benthic microbial fuel cells toward sustainable bioremediation and renewable energy production. International Journal of Environmental Research and Public Health 18, 3811

Velasquez-Orta SB, Curtis TP, Logan BE (2009): Energy from algae using microbial fuel cells. Biotechnology and bioengineering 103, 1068-1076

Vilariño MV, Franco C, Quarrington C (2017): Food loss and waste reduction as an integral part of a circular economy. Frontiers in environmental science 5, 21 
Wang H, Song X, Zhang H, Tan P, Kong F (2020): Removal of hexavalent chromium in dualchamber microbial fuel cells separated by different ion exchange membranes. Journal of hazardous materials 384,121459

Wen Q, Wu Y, Cao D, Zhao L, Sun Q (2009): Electricity generation and modeling of microbial fuel cell from continuous beer brewery wastewater. Bioresource technology 100, 41714175

Xu L, Zhao Y, Doherty L, Hu Y, Hao X (2016): The integrated processes for wastewater treatment based on the principle of microbial fuel cells: a review. Critical Reviews in Environmental Science and Technology 46, 60-91

Xu P, Xiao E-R, Xu D, Zhou Y, He F, Liu B-Y, Zeng L, Wu Z-B (2017): Internal nitrogen removal from sediments by the hybrid system of microbial fuel cells and submerged aquatic plants. PloS one 12 , e 0172757

Yaqoob AA, Ibrahim MNM, Yaakop AS, Umar K, Ahmad A (2020a): Modified Graphene Oxide Anode: A Bioinspired Waste Material for Bioremediation of Pb2+ with Energy Generation through Microbial Fuel Cells. Chemical Engineering Journal, 128052

Yaqoob AA, Khatoon A, Mohd Setapar SH, Umar K, Parveen T, Mohamad Ibrahim MN, Ahmad A, Rafatullah M (2020b): Outlook on the Role of Microbial Fuel Cells in Remediation of Environmental Pollutants with Electricity Generation. Catalysts 10, 819

Yaqoob AA, Mohamad Ibrahim MN, Rafatullah M, Chua YS, Ahmad A, Umar K (2020c): Recent Advances in Anodes for Microbial Fuel Cells: An Overview. Materials 13, 2078

Yaqoob AA, Ibrahim MNM, Yaakop AS (2021a): Application of oil palm lignocellulosic derived material as an efficient anode to boost the toxic metal remediation trend and energy generation through microbial fuel cells. Journal of Cleaner Production, 128062 
693 Yaqoob AA, Mohamad Ibrahim MN, Umar K, Bhawani SA, Khan A, Asiri AM, Khan MR, Azam 694 M, AlAmmari AM (2021b): Cellulose Derived Graphene/Polyaniline Nanocomposite 695 Anode for Energy Generation and Bioremediation of Toxic Metals via Benthic Microbial $696 \quad$ Fuel Cells. Polymers 13, 135

697 Zhang J, Cao X, Wang H, Long X, Li X (2020): Simultaneous enhancement of heavy metal 698 removal and electricity generation in soil microbial fuel cell. Ecotoxicology and $699 \quad$ Environmental Safety 192, 110314

700 Zhang L, Zhou S, Zhuang L, Li W, Zhang J, Lu N, Deng L (2008): Microbial fuel cell based on $701 \quad$ Klebsiella pneumoniae biofilm. Electrochemistry communications 10, 1641-1643

702 